\title{
Assessment of Use in Clinical Practice of Internal Medicine Nursing Practice Student Training Module
}

\author{
Nuray Enç ${ }^{1}$, Havva Alkan², Hilal Uysal ${ }^{2 *}$, Gülbeyaz Can ${ }^{1}$, Zeliha Tülek ${ }^{3}$ \\ ${ }^{I}$ Professor, PhD, RN, Istanbul Universitesi-Cerrahpaşa Florence Nightingale Faculty of Nursing, Internal \\ Medicine Nursing Department \\ ${ }^{2}$ Assistant professor, PhD, RN, Istanbul Universitesi-Cerrahpaşa Florence Nightingale Faculty of Nursing, \\ Internal Medicine Nursing Department \\ ${ }^{3}$ Associate Professor, PhD, RN, Istanbul Universitesi-Cerrahpaşa Florence Nightingale Faculty of Nursing, \\ Internal Medicine Nursing Department
}

*Corresponding Author: Hilal Uysal, Istanbul Universitesi-Cerrahpaşa Florence Nightingale Faculty of Nursing Abide-i Hurriyet Cd. 34387 Sisli /Istanbul/ Turkey. Email: hilaluysal@ gmail.com

\begin{abstract}
Introduction \& Purpose: During internal medicine nursing practice, student nurses need a diagnostic tool to guide comprehensively determine their care needs of patients with different health problems. The purpose of this study, which contributes to practice education in internal medicine nursing, to evaluate usability of Internal Medicine Nursing Practice Student Training Module which based on the model of Gordon's functional health patterns by students.
\end{abstract}

Methods: Research, at a state university's nursing faculty, 2014-2017 academic years, Internal Medicine Nursing course who agreed to participate in the study with 877 second grade students were performed. Data were collected by questionnaire containing of 10 questions related to the use of student training module. Frequency distribution was used the evaluating of the data.

Results: Of the students who participated in the research, $84.6 \%$ were female, $15.4 \%$ were male and the mean age was $20.01 \pm 1.413$. The majority of students were undecided about the benefit of using the module in clinical practice. However, he found that those who thought it useful were more than those who thought it was not useful. In the study, it was determined that female students performed better patient diagnosis, diagnosed criteria and diagnosis, case analysis than males.

Discussion and Conclusion: The goal of health care services is to provide quality care. As a health care worker, it is imperative that nurses use the nursing models and theories to plan patient care in a planned manner based on scientific principles. In this study, it is generally concluded that Internal Medicine Nursing Practice Student Training Module is useful for patient diagnosis, diagnosis criteria and nursing diagnosis.

Keywords: Students, nursing, internal medicine, education.

\section{INTRODUCTION}

New requirements and demands in the field of health, scientific information content, developments in medical science and technology affect nursing (Güner \& Terakye, 2000). Modern nursing adopts a systematic approach to organizing and maintaining care, with the modern roles it undertakes, to enable the individual to receive the best nursing care. This approach is the nursing process. The nursing process is a method used to present individualized care in determining and eliminating problems (Keski \& Karadağ, 2010). The implementation of the nursing process facilitates the effective use of time and labor force for the purpose, as it provides the opportunity to determine priorities in the care to be given (Karadakovan, 2004).

However, it is necessary to use the nursing process together with a nursing model in order to achieve a systematic and evidence-based scientific approach. The care given in this way will be appropriate to meet the individual's needs (Kaya, Babadağ, Yeşiltepe Kaçar \& Uygur, 2010). In 1987, Marjory Gordon developed a leri Functional Health Pattern (SRS) Model "that addresses individuals in a comprehensive bio-psycho-social dimension and explains the care needs of individuals in 11 functional areas. Eleven areas in the model, 
systematic and standardized information collection approach and nursing perspective provides information to analyze. Gordon's FSS enables nurses to perform an individualized comprehensive assessment of patient care and to apply the nursing process (Erdemir \& Yilmaz, 2005).

Internal Medicine Nursing lesson is a secondyear lesson. Students begin to learn the theoretical knowledge and application skills of diseases in this period. Therefore, because the theoretical and practical skills of the students are not sufficient in clinical practice, patient evaluations are insufficient. Gordon's FSÖ model allows students to analyze the individual from a bio-psycho-social perspective in order to collect systematic and standardized information from a nursing perspective. Students will be able to collect data more quickly after they have understood this systematic and prioritize them and plan and implement the necessary initiatives to solve the problems identified. Therefore, based on Gordon's Functional Health Patterns Model, Internal Medicine Nursing Practice Student Training Module was created (Enç, Can, Özcan, Tülek, Uysal \& Alkan, 2012). Functional health patterns are a model that can be used to assess human / human reactions in young or old, female or male, all areas and at any health level, in acute / chronic conditions and in any medical diagnosis (Erdemir \& Yilmaz, 2005).

In the internal medicine nursing lesson, in 2012, we used the Internal Medicine Nursing Practice Student Training Module in clinical practice. By using the module in practice, it is aimed that the students diagnose the patient, identify the problems and plan the attempts for the problems, make the system of application and evaluation in a systematic way and develop their critical thinking skills.

\section{MeTHODS}

Design and Sample: This study was planned and implemented as a descriptive study in order to evaluate the use of the Internal Medicine Nursing Practice Student Training Module. The research was conducted in the nursing faculty of a public university in 2014-2016 in two academic years. The study was carried out as a descriptive study with 877 second grade students who were trained in the clinical practice of Internal Medicine Nursing course and accepted to participate in the research. There were no students who refused to participate in the study at the specified dates and the whole universe was reached.

\section{Research Questions}

1. Students think which steps of the Internal Medicine Nursing Practice Student Training Module are useful?

2. Are there any differences according to sociodemographic characteristics of students in their thoughts about the usefulness of the use of the module in clinical practice?

\section{Data Collection}

The questionnaire used in the study was prepared by the researchers in order to evaluate the thoughts of the module on the use of clinical practice by the students in the scope of internal medicine nursing practice student training module. The questionnaire includes questions about the individual characteristics of the students such as age, gender, high school, graduation status, health insurance, income level. There are 10 questions about the usefulness of the module while performing the nursing process during the clinical practice of internal medicine nursing. There is also a question in the questionnaire where students ask for additional ideas and suggestions regarding the use of the module.

\section{Data Analysis}

All analyzes were performed on computer in İ.Ü. Statistical Package for Social Sciences (SPSS) was performed using 21 package programs. In the evaluation of parametric variables, arithmetic mean, standard deviation, frequency and percentage tests were used to evaluate nonparametric variables. The value of significance was accepted as $\mathrm{p}<0.05$.

\section{Ethical Issues}

Participation in the study was based on a voluntary basis. Informed consent was obtained from the students who accepted to participate after the necessary explanations and the questionnaires were given to the students. All expenses of the research were covered by the researchers.

\section{Results}

In this study, $84.6 \%$ of the students were female, $15.4 \%$ were male and the mean age was $20.01 \pm 1.413$. The majority of the students $(93.7 \%)$ were graduated from Anatolian-Science High School and only eigtht students were graduated from health vocational high school (Table 1). 
Table1. Socio-Demographic Characteristics $(N=877)$

\begin{tabular}{|l|c|}
\hline & $\mathbf{N}(\%)$ \\
\hline Age (Mean \pm SD) & $20.01 \pm 1.413$ \\
\hline Gender & $742(84.6)$ \\
\hline Female & $135(15.4)$ \\
\hline Male & $822(93.7)$ \\
\hline Education Status & $8(0.9)$ \\
\hline High School & $47(5.4)$ \\
\hline Health Vocational High School & $327(37.3)$ \\
\hline Other Vocational High School & $348(39.7)$ \\
\hline Internship Made Section & $202(23.0)$ \\
\hline Istanbul University Istanbul Faculty of Medicine & $35(4.0)$ \\
\hline Istanbul University-Cerrahpaşa Cerrahpaşa Faculty of & $842(96.0)$ \\
\hline Medicine & \\
\hline Istanbul University-Cerrahpaşa Cardiology Institute & $73(8.3)$ \\
\hline Work Status & $804(91.7)$ \\
\hline Yes & \\
\hline No & $790(90.1)$ \\
\hline Economical Situation & $87(9.9)$ \\
\hline Bad & \\
\hline Good & \\
\hline Social Security & \\
\hline Yes & \\
\hline No & \\
\hline Th majority Of the & \\
\hline
\end{tabular}

The majority of the students were undecided about the usefulness of the Internal Medicine Nursing Practice Student Training Module.

However, it was found that those who think that it is beneficial are more than those who think it is not useful (Table 2).

Table2. Students' thoughts about the benefit of using in the clinical practice of the Internal Medicine Nursing Practice Student Training Module $(N=877)$

\begin{tabular}{|c|c|c|c|c|c|}
\hline & Not useful at all & Not a little useful & Undecided & A little useful & Very helpful \\
\hline & $\mathbf{N}(\%)$ & $\mathbf{N}(\%)$ & $\mathbf{N}(\%)$ & $\mathbf{N}(\%)$ & $\mathbf{N}(\%)$ \\
\hline Patient diagnosis & $14(1.6)$ & $97(11.1)$ & $338(38.5)$ & $353(40.3)$ & $75(8.6)$ \\
\hline $\begin{array}{l}\text { Determining } \\
\text { diagnostic criteria } \\
\text { (signs and symptoms) }\end{array}$ & $7(0.89$ & 104(11.9) & $319(36.4)$ & $319(42.8)$ & $72(8.2)$ \\
\hline \begin{tabular}{llr} 
Interpret & \multicolumn{2}{c}{ diagnostic } \\
criteria & (signs & and \\
findings) & &
\end{tabular} & $10(1.1)$ & 131(14.9) & $389(44.4)$ & $281(32.0)$ & $66(7.5)$ \\
\hline $\begin{array}{l}\text { Determining the } \\
\text { diagnosis of nursing }\end{array}$ & $10(1.1)$ & $80(9.1)$ & $308(35.1)$ & $360(41.0)$ & 119(13.6) \\
\hline $\begin{array}{l}\text { Determining the cause } \\
\text { of the problem }\end{array}$ & $8(0.9)$ & 147(16.8) & 429(48.9) & $249(28.4)$ & $44(5.0)$ \\
\hline Objective / goal setting & $6(1.0)$ & 144(16.4) & $390(44.5)$ & $282(32.2)$ & $52(5.9)$ \\
\hline $\begin{array}{l}\text { Creating nursing } \\
\text { interventions }\end{array}$ & $9(1.0)$ & $163(18.6)$ & $333(38.0)$ & $301(34.3)$ & $71(8.1)$ \\
\hline Evaluation & $11(1.3)$ & $166(18.9)$ & $393(44.8)$ & $244(27.8)$ & $63(7.2)$ \\
\hline Nursing report & $15(1.79$ & $184(21.0)$ & $385(43.9)$ & $237(27.0)$ & $56(6.49$ \\
\hline Case analysis & $17(1.9)$ & $168(19.2)$ & $377(43.0)$ & $243(27.79$ & $72(8.2)$ \\
\hline
\end{tabular}

In the research, it was determined that women had better patient diagnosis, determined the diagnostic criteria and diagnosis, and had the ability to perform case analysis. However, it was found that the ability of men to interpret the diagnostic criteria, to determine the cause, purpose / goal, to create the interventions, to evaluate and to report was better than that of women (Table 3). In this study, it was determined that nursing students who are graduates of health vocational high schools could apply their nursing process skills to a better level by using the Student Training Module (Table 3). In the study, the ability of the students who did not work in any job to perform the nursing process steps by using the module was found to be higher than the students who were working and they were found to benefit more than using the module (Table 3 ). 
Table3. Evaluation of the usefulness of the using of the the Internal Medicine Nursing Practice Student Training Module in clinical practice according to sociodemographic characteristics $(N=877)$

\begin{tabular}{|c|c|c|c|c|c|c|c|c|c|c|}
\hline & Diagnostic & $\begin{array}{l}\text { Determining } \\
\text { diagnostic } \\
\text { criteria }\end{array}$ & $\begin{array}{l}\text { Interpret I } \\
\text { diagnostict } \\
\text { criteria }\end{array}$ & $\begin{array}{l}\text { Determining } \\
\text { the diagnosist } \\
\text { of nursing }\end{array}$ & $\begin{array}{l}\text { Determining } \\
\text { the cause of } \\
\text { the problem }\end{array}$ & $\begin{array}{l}\text { Objective/ } \\
\text { goal } \\
\text { determining }\end{array}$ & $\begin{array}{l}\text { Creating } \\
\text { nursing } \\
\text { interventions }\end{array}$ & Evaluation & $\begin{array}{c}\text { Nursing } \\
\text { report }\end{array}$ & $\begin{array}{l}\text { Case } \\
\text { analysis }\end{array}$ \\
\hline \multicolumn{11}{|l|}{ Gender } \\
\hline $\begin{array}{l}\text { Female } \\
(\mathrm{N}=742)\end{array}$ & $3.45 \pm 0.83$ & $3.46 \pm 0.82$ & $3.28 \pm 0.83$ & $3.58 \pm 0.84$ & $3.19 \pm 0.79$ & $3.24 \pm 0.81$ & $3.29 \pm .88$ & $3.19 \pm 86$ & $3.14 \pm 86$ & $3.22 \pm 90$ \\
\hline Male (N=135) & $3.33 \pm 0.97$ & $3.44 \pm 0.92$ & $339 \pm 0.93$ & $3.53 \pm 1.02$ & $3.22+0.88$ & $333 \pm 0.93$ & $336 \pm 98$ & $330 \pm 94$ & $3.23 \pm 99$ & $3.16 \pm 96$ \\
\hline \multicolumn{11}{|l|}{\begin{tabular}{|l|} 
Education \\
Status \\
\end{tabular}} \\
\hline \begin{tabular}{|l|} 
High \\
School $(\mathrm{N}=822)$
\end{tabular} & $3.43 \pm 85$ & $3.45 \pm 83$ & $3.30 \pm 85$ & $3.57 \pm 87$ & $3.20 \pm 80$ & $3.26 \pm 82$ & $3.29 \pm .89$ & $3.20 \pm 86$ & $3.15 \pm 87$ & $3.21 \pm 90$ \\
\hline \begin{tabular}{|l|} 
Health \\
Vocational \\
HighSchool \\
$(\mathrm{N}=8)$
\end{tabular} & $4.13 \pm 99$ & $3.88 \pm 64$ & $3.88 \pm 64$ & $3.75 \pm 1.03$ & $3.38 \pm 1.06$ & $3.88 \pm 83$ & $3.38 \pm 1.06$ & $3.88 \pm 99$ & $3.38 \pm 1.06$ & $3.50 \pm 1.19$ \\
\hline $\begin{array}{l}\text { Other } \\
\text { Vocational } \\
\text { HighSchool } \\
(\mathrm{N}=47) \\
\end{array}$ & $3.38 \pm 76$ & $3.55 \pm 85$ & $3.26 \pm 79$ & $3.57 \pm 92$ & $3.15 \pm 88$ & $3.15 \pm 1.02$ & $3.40 \pm 1.01$ & $3.17 \pm 94$ & $3.13 \pm 96$ & $3.11 \pm 1.00$ \\
\hline \multicolumn{11}{|l|}{ WorkStatus } \\
\hline $\operatorname{Yes}(\mathrm{N}=35)$ & $3.51 \pm 85$ & $3.51 \pm 83$ & $3.40 \pm .85$ & $3.60 \pm 87$ & $3.17 \pm 80$ & $3.37 \pm 83$ & $3.40 \pm .89$ & $3.29 \pm 98$ & $3.29 \pm 92$ & $3.11 \pm 93$ \\
\hline $\mathrm{No}(\mathrm{N}=842)$ & $351 \pm 98$ & $351 \pm 95$ & $3.40 \pm .91$ & $3.60 \pm 1.00$ & $3.17 \pm 78$ & $337 \pm 94$ & $3.40 \pm 1.06$ & $3.20 \pm 86$ & $3.15 \pm 88$ & $3.21 \pm 91$ \\
\hline \multicolumn{11}{|l|}{\begin{tabular}{|l|} 
Economical \\
Situation
\end{tabular}} \\
\hline $\operatorname{Bad}(\mathrm{N}=73)$ & $3.33 \pm 97$ & $3.38 \pm 92$ & $3.25 \pm 94$ & $3.36 \pm 99$ & $3.08 \pm 98$ & $3.14 \pm 94$ & $3.25 \pm 1.03$ & $3.23 \pm 96$ & $3.12+95$ & $3.15 \pm 1.02$ \\
\hline $\operatorname{Good}(\mathrm{N}=804)$ & $3.44 \pm 84$ & $3.46 \pm 82$ & $330 \pm 84$ & $3.59 \pm 86$ & $3.21 \pm 78$ & $3.27 \pm 82$ & $3.30 \pm 88$ & $3.21 \pm 86$ & $3.16 \pm 87$ & $3.22 \pm 90$ \\
\hline
\end{tabular}

The results of our study showed that the students with the income level had better benefits than the ones using the module (Table 3). In this study, According to the gender the views of the use of modules to implement nursing process steps are examined; In both sexes, it was determined that the use of the module was in the majority of students a little useful tool for diagnosing $\left(\chi^{2}=13.43 \mathrm{p}=0.009\right)$, and determining the nursing diagnosis $\left(\chi^{2}=10.74\right.$ $\mathrm{p}=0.03)$. However, to determine the diagnostic criteria $\left(\chi^{2}=5.63 \mathrm{p}=0.22\right)$, to interpret the diagnostic criteria $\left(\chi^{2}=6.24 \quad \mathrm{p}=0.18\right)$, to determine the cause of the problem $\left(\chi^{2}=4.98\right.$ $\mathrm{p}=0.28)$, to determine the purpose and target $\left(\chi^{2}=8.28 \quad \mathrm{p}=0.08\right)$ to establish nursing interventions $\left(\chi^{2}=6.81 \mathrm{p}=0.14\right)$, to make evaluation $\left(\chi^{2}=4.99 \mathrm{p}=0.28\right)$, to establish nursing report $\left(\chi^{2}=17.20 \mathrm{p}=0.002\right)$ and to perform case analysis $\left(\chi^{2}=1.77 \mathrm{p}=0.77\right)$ it was found that they were undecided about the usefull of using of the module (Table 3).

\section{Thoughts and Suggestions of the Students on the Use of the Module}

They stated that the module was useful but could not get enough benefit because the duration of clinical practice was limited. The students stated that the contents of the module were intensive according to the time spent with the patient. It was stated that the module provided benefit to the student in order to create a care plan and to communicate with the patient. This thought suggests that the module has reached its intended use. However, they thought that the module was difficult to use in patients with inpatients for a short period of time.

The module is stated to provide convenience for diagnosis. The students stated that the module was useful in terms of understanding and diagnosing the nursing diagnoses of the module and planning the appropriate nursing interventions. However, they stated that they experienced problems such as time limitation and lack of theoretical knowledge during the implementation phase.

\section{DISCUSSION}

The goal of health care services is to give quality care. In order to achieve this, nurses as a health care worker are obliged to apply patient care in a planned manner using nursing models and theories based on scientific foundations. For the collection of data from a healthy / sick individual and his / her family with a systematic approach, the use of models developed by 
theoreticians will facilitate $\mathrm{o}$ provide and maintain of patient care. Gordon's functional health pattern model is one of the most important models that examines the individual from a bio-psycho-social perspective with a holistic approach (Sabancioğlu, Ata, Kelleci \& Doğan, 2011).

The first step in the nursing process is diagnosis. This step takes place through clinical data collection or patient interviews. In order to achieve this step, nurses need to understand the individual's bio-psycho-social dimension, spiritual needs, growth and development process, pathophysiology, familial status and culture, beliefs and values (Aziz Alimul Hidayet $\&$ Kes, 2015). In this context, it was found that among the nursing students participating in the study, it was found that women were better than men in determining patient evaluation, diagnostic criteria and make diagnosis, and case analysis. In addition, it was found thatmale students were better than female students in the able to interpret diagnostic criteria, determine cause, aim / target, create interventions, evaluate and report (Tablo 3). In general, in national and international studies, it was stated that nursing students experienced problems in theoretical knowledge and practice to perform the nursing process and did not know exactly how to apply the nursing process (Şendir, Acaroğlu \& Aktaş, 2009; Lea, Anema, Briscoe \& Allie, 2001; GökÖzer \& Kuzu, 2006).

In the data collection phase, the implementation of the other stages of the nursing process will not be successful if the information received from the patient and his / her family are not accurate and sufficient. In order to be able to make the correct nursing diagnose, will help to make an accurate diagnosis, to determine the diagnostic criteria of the patient, to determine the cause of the problem and hence determine the goals / objectives necessary to eliminate the problem (Gouveia Dias Bittencourt \& Oliveveira Crossetti, 2013).

In this study, it was determined that nursing students who are graduates of health vocational high schools could apply their nursing process skills to a better level by using the Student Training Module (Table 3). In a study, it was found that nurses had difficulty with "often" in collecting data, diagnosing nursing and identifying interventions (Andsoy, Güngör, Dikmen \& Nabel, 2013). This situation shows that students should be able to gain more practical skills on the implementation of the nursing process during nursing education. For this purpose, which provides a systematic approach to internal medicine nursing, is intended to be utilized in the nursing process from Gordon's functional health patterns model. It is thought that the prepared module will complete a significant deficiency in this respect.

Nursing assessment forms should only be established to address the patient's nursing care needs. The forms should be created with a different perspective from the physician evaluation forms and should be special. In Indonesia, it is stated that physician evaluation forms are used for nursing assessment in many hospitals (Aziz Alimul Hidayet \& Kes, 2015).

In our study, the majority of the students stated that they thought the use of the module was a little useful for diagnosing the diagnosis of nursing. However, the students stated that they were undecided about the usefulness of the module to identify and interpret diagnostic criteria, to determine the cause of the problem, to identify the objective / goal, to establish the nursing interventions, making the evaluation, to create the nursing report and to performe case analysis (Table 3). Critical thinking is a basic skill required in nursing diagnostic process. Critical thinking is a clinical judgment to interpret, analyze, evaluate and conclude data, as well as an explanation of the evidence on which the clinical judgment is based. Nowadays, difficulties are still encountered in the development of critical thinking skills in nursing education and especially in the nursing diagnosis process (Gouveia Dias Bittencourt \& Oliveveira Crossetti, 2013). In order to make correct nursing diagnose, theoretical knowledge and application skills are needed to understand possible situations, causal factors, the mechanisms used to determine the mechanism of the disease process and the measurements used to determine the problems, and to reach critical results (Aziz Alimul Hidayet \& Kes, 2015). For this reason, students' should adopt and analyze factors such as analysis, technical and scientific knowledge, logical reasoning, clinical experience, knowledge about the patient, application of standards, perception and contextual viewpoint in order to develop critical thinking skills (Gouveia Dias Bittencourt \& Oliveveira Crossetti, 2013). According to the findings of the study, it is seen that students do not have enough critical thinking skills in order to understand and apply the nursing process steps. It is thought that they have difficulties in logical reasoning as there is insufficient clinical experience and theoretical knowledge. 
Nursing diagnosis, which is the second stage of the nursing process, is the result of the synthesis of all data. The diagnosis of nursing consists of three parts which include the individual's problem, etiological factors and descriptive characteristics (Demir Doğan, 2017). In the literature, it is stated that nursing students have difficulty in data analysis and in using the correct terminology and could not do the correct etiological classification of nursing diagnoses (Aydin \& Akansel, 2013). In the studies conducted, it was determined that nursing students have difficulty in different stages of nursing process in clinical applications. It was determined that nursing students focused on medical diagnosis rather than nursing diagnosis and focused on medical problems that could not be solved by nursing interventions. It was determined that the students had difficulty in separating the diagnostic criteria due to the problem, and that the medical diagnosis and symptoms were expressed as the diagnosis of nursing (Güner \& Terakye, 2000; Kaya, Babadağ, Yeşiltepe Kaçar \& Uygur, 2010; GökÖzer \& Kuzu, 2006; Aydin \& Akansel, 2013). In a study, it was determined that $65.6 \%$ of the students were able to determine the diagnostic criteria, $64.1 \%$ were able to determine the cause of the problem, $68.8 \%$ were able to determine the expected results, $32.7 \%$ were able to make planning / application and $46.2 \%$ were successful in the evaluation. In general, it was determined that they were insufficient in fulfilling the diagnostic criteria and the planning / implementation phase in the same study (GökÖzer \& Kuzu, 2006).

In this study, it is unstable to apply nursing process by using Internal Medicine Nursing Practice Student Module in clinical practice. However, it was found that those who thought that the module was useful were more than those who thought it was not useful (Table 2). It is stated that theoretical knowledge, clinical experience and cognitive development competence can affect the performance of students in relation to nursing care plans (Aydin \& Akansel, 2013). In the studies (Aydin \& Akansel, 2013; Can, \& Erol, 2012; James \& Chapman, 2009), it was stated that nursing students may have anxiety before and during the clinical practice because they feel the inadequacy and have little professional nursing skills and inadequate theoretical knowledge. In a study, it was stated that there are important information deficiencies related to all stages of nursing process of nursing students (Keski \& Karadağ, 2010). It is thought that this may be the reason why students are undecided about the use of the module. It is concluded that students need to practice more on the patients in order to fully to apply and understand the stages of the nursing process (Table 2). Hakverdioğlu Yönt, et al. (2009), reported that second-year nursing students may have more difficulty in identifying nursing diagnoses and in evaluating patients since their clinical experience is less than third and fourth-year students. Therefore, it is stated that students will feel inadequate in nursing activities (Hakverdioğlu Yönt, et al., 2009). In one study, however, nursing students stated that they were very adequate in data collection and planning nursing interventions to determine the nursing diagnosis. Similarly with our study in the same study, in order to make nursing diagnosis, it was determined that were the majority of students who thought that they could evaluate the patient fully and plan nursing interventions (Brysiewicz \& Lee, 2009).

Nursing diagnosis and evaluation are part of the nursing process that helps nurses in problem solving (Aziz Alimul Hidayet \& Kes, 2015. The evaluation phase forms the basis for all stages of the nursing process (Taskin Yilmaz , Sabanciogullari, \& Aldemir, 2015). In the literature, it was stated that the physician evaluation forms were used to evaluate the patient instead of the nursing evaluation forms and these forms would not be sufficient to obtain accurate information from the patient. An effective implementation strategy is required for assessment and nursing diagnoses. This strategy increases the accuracy of nursing diagnoses. For this reason, the fact that the module consisting of 11 functional patterns of Gordon is reflected in the clinic as a patient diagnostic and evaluation form is an important development for the rapid improvement of patient results (Aziz Alimul Hidayet \& Kes, 2015). The internal education nursing practice student training module that developed with the help of the functional health patterns model, offers a systematic approach to categorize nursing diagnoses and to complete the physical examination and evaluation. 


\section{CONCLUSION AND RECOMMENDATIONS}

In conclusion, in the study, nursing students stated that the use of the internal education nursing practice student training module in clinical practice is useful to diagnose the patient, determining the diagnostic criteria and making nursing diagnosis. It was determined that students had difficulty completing nursing care due to time limitations and lack of theoretical knowledge. The use of the module in clinical practice by nursing students will increase their self-confidence while applying daily nursing interventions, will enable them to correctly and rapidly establish their nursing diagnoses, and will facilitate the effective use of time and labor force for the purpose.

In clinical practice, it is essential that a wellorganized effective model is implemented in order to enable the nursing process to be applied easily and to provide the right approach to the individual / family (Güner \& Terakye, 2000). The integration of nursing diagnoses and evaluations, evaluation of each functional pattern will be more effective and easier with the module. The module will also facilitate of nursing students to make nursing care records.

It will make it easier for the students to learn more cases reviews by using the module to better understand the nursing process. Therefore, it will help students to develop a large number of nursing processes in clinical practice and to develop their skills in organizing seminars and discussing their deficiencies.

\section{DISCLOSURES}

The authors declare there is no conflict of interest.

*This study was presented as a poster paper in 2017 ICESLT, 3RD International Congress on Education Sciences and Learning Technology on 15-19 November 2017 in Athens Greece.

\section{ACKNOWLEDGEMENTS}

The authors would like to thank all the students who participated in the study.

\section{AUTHORSHIP STATEMENT}

The listed authors meet the criteria for authorship and agree with the content of the manuscript. NE, HA and HU designed the study and prepared the manuscript. HA, HU, ZT collected the data. HU, GC and NE analysed the data and prepared the manuscript. All authors approved the final version for submission ans all authors are in agreement with the content of the manuscript.

\section{REFERENCES}

[1] Güner P, \& Terakye G. (2000). The level of determination nursing diagnosis of senior nursing school students. Cumhuriyet University Journal of School of Nursing 4(1):9-15.

[2] Keski Ç, \& Karadağ A. (2010). Investigation of Knowledge Levels of Final Year Nursing Students Regarding Nursing Process. HEMARG 1:41-52.

[3] Karadakovan A, (2004). Usta Yeşilbalkan Ö. The Investigation of the NANDA Nursing Diagnosis Determined by the Students on Neurological Patient. Atatürk University Journal of School of Nursing 7(3):1-7.

[4] Kaya N, Babadağ K, Yeşiltepe Kaçar G, \& Uygur E. (2010). Nurses' Nursing Model / Theory, Nursing Process, and Classification Systems Know and Implication Status. Maltepe University Journal of Nursing Science and Art 3(3):24-33.

[5] Erdemir F, \& Yılmaz E (ed.). (2005). Nursing Classification Systems, Clinical Practice, Education, Research and Use in Management. [Hemsirelik Sinıflama Sistemleri, Klinik Uygulama, Egitim, Arastırma ve Yönetimde Kullanımı.] Nursing Classification Systems Symposium Book. 1. Edition, Başkent University Publication, Ankara.

[6] Enç N, Can G, Özcan Ş, Tülek Z, Uysal H, \& Alkan H. (2012). Internal Medicine Nursing Practice Student Training Module. [İç Hastalıkları Hemşireliği Uygulama Öğrenci Eğitim Modülü.] Nobel Tıp Kitapevleri, İstanbul, p.7-39.

[7] Sabancioğlu S, Ata EE, Kelleci M, \& Doğan S. (2011) Evaluation According to the Functional Health Pattern Model and NANDA Diagnoses of Patient Care Plans Made by Nurses in a Psychiatry Department. Journal of Psychiatric Nursing 2(3):117-122.

[8] Aziz Alimul Hidayet A, \& Kes M. (2015). Model documentation of assessment and nursing diagnosis in the practice of nursing care management for nursing students. International Journal of Advanced Nursing Studies 4(2):158163.

Doi: https://doi.org/10.14419/ijans.v4i2.5116

[9] Şendir M, Acaroğlu R, \& Aktaş A. (2009). Nursing school senior students' views on nursing. Florence Nightingale Journal of School of Nursing 17(3):166-173.

[10] Lea SF, Anema MG, Briscoe VJ, \& Allie H. (2001). The nursing process: What do students know? The Association of Black Nursing Faculty Journal 12(1):3-8.

[11] Gök-Özer F, \& Kuzu N. (2006). The nursing process in students' care plans and the use of NANDA diagnoses. Ege University Journal of School of Nursing 22(1):69-80. 
[12] Gouveia Dias Bittencourt GK, \& Oliveveira Crossetti MG. (2013). Critical thinking skills in the nursing diagnosis process. Rev Esc Enferm USP 47(2):337-43.

[13] Andsoy II, Güngör T, Dikmen Y, \& Nabel EB. (2013). Hemşirelerin bakım planını kullanırken yaşadıkları güçlükler. Journal of Contemporary Medicine 3(2):88-94.

[14] Demir Doğan M. (2017). Nursing Diagnoses Determined by Second Year Students. Journal of Patient Care 3(1):1-3.

[15] Aydin N, \& Akansel N. (2013). Determination of Accuracy of Nursing Diagnoses Used by Nursing Students in their Nursing Care Plans. International Journal of Caring Sciences 6(2):252-257.

[16] Can G, \& Erol O. (2012). Nursing Students' Perceptions about nursing care plans: A Turkish perspective, International Journal of Nursing Practice 8:12-19.
[17] James A, \& Chapman Y. (2009). Preceptors and patients- the power of two: nursing student experiences on their first acute clinical placement, Contemporary Nurse 34(1):34- 47.

[18] Hakverdioğlu Yönt G, Khorshid L, \& Eşer İ. (2009). Examination of Nursing Diagnoses Used by Nursing Students and Their Opinions About Nursing Diagnoses. International Journal of Nursing Terminologies and Classifications 20(4):162-168. doi: 10.1111/j.1744-618X.2009 $.01131 . \mathrm{x}$

[19] Brysiewicz P, \& Lee MB. (2009). Nursing students' evaluation of the introduction of nursing diagnosis focused tutorials in a university degree programme. Curationis 32(1):20-24.

[20] Taskın Yilmaz F, Sabanciogullari S, \& Aldemir K. (2015). The Opinions of Nursing Students Regarding the Nursing Process and Their Levels of Proficiency in Turkey. J Caring Sci 4(4):265-275. Doi: 10.15171/jcs.2015.027

Citation: Nuray Enç, Havva Alkan, Hilal Uysal, Gülbeyaz, Can, Zeliha Tülek. Assessment of Use in Clinical Practice of Internal Medicine Nursing Practice Student Training Module. ARC Journal of Nursing and Healthcare. 2019; 5(1):1-8. doi: dx.doi.org/ 10.20431/2455-4324.0501001.

Copyright: (C) 2019 Authors. This is an open-access article distributed under the terms of the Creative Commons Attribution License, which permits unrestricted use, distribution, and reproduction in any medium, provided the original author and source are credited. 